\title{
MENGELOLA CORPORATE CRISIS MELALUI TRANSFORMASI MODEL STAKEHOLDER RELATIONS DI ERA DIGITAL
}

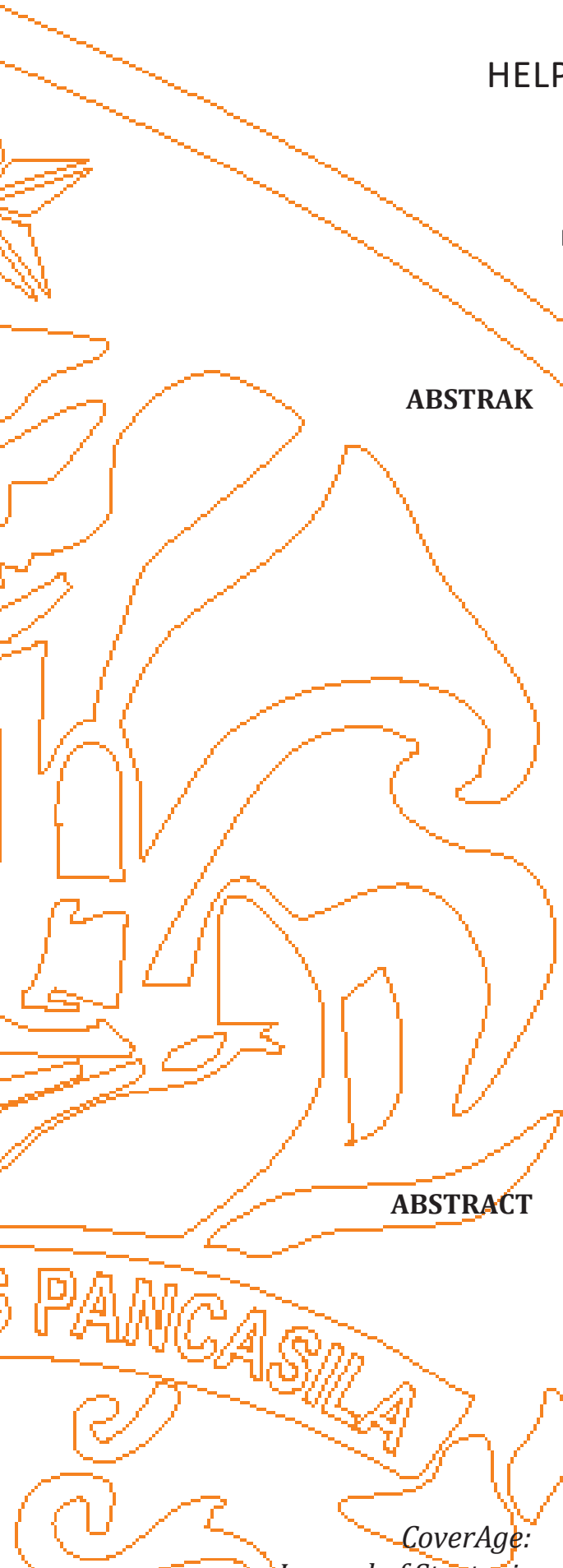

Journal of Strategic

Communication

Vol. 9, No. 1, Hal. 1-16.

September 2018

Fakultas Ilmu Komunikasi, Universitas Pancasila

Diterima 2 April 2018

Disetujui 15 Agustus 2018
Universitas Pancasila, Jakarta, Indonesia

Jl. Srengseng Sawah, Jagakarsa, Jakarta Selatan

Email: the.estaswara@yahoo.com | Hp: 081310488088

Email: dachsp@cbn.net.id | Hp: 081519332038
Mengetola stakeholder di era masyarakat digital menjadi lebih rumit terlebih dalam menangani krisis di perusahaan. Akibatnya, untuk mengembangkan hubungan menguntungkan jangka panjang dengan para pemangku kepentingan membutuhkan metode berbasis dialog. Namun, banyak model hubungan pemangku kepentingan dalam implementasi perusahaan tetap berasal dari pemahaman bahwa perusahaan adalah pusat dari semua pemangku kepentingan, atau model yang berpusat pada perusahaan. Model baru sistem-sentris di era masyarakat digital telah diusulkan yang terkait dengan para pemangku kepentingan. Model ini menyiratkan bahwa perusahaan tidak akan lagi menjadi pusat pemangku kepentingan. Ini berarti posisi perusahaan menjadi bagian dari sistem dan melibatkan strategi komunikasi dua arah yang simetris. Tulisan ini bertujuan, pertama untuk mengelaborasi jaringan sosial yang berpotensi menciptakan krisis jika perusahaan tidak menerapkan model sistem-sentris yang membutuhkan pengembangan dialog pembelajaran multi-pemangku kepentingan. Kedua, juga menganalisis langkah-langkah yang harus dipertimbangkan untuk mengubah model tradisional menuju model komunikasi simetris hubungan pemangku kepentingan. Selain itu, metode tinjauan pustaka diterapkan sebagai dasar konstruksi teoritis pada model hubungan pemangku kepentingan yang harus dilibatkan dalam menghindari krisis.

Kata Kunci: Krisis perusahaan, pemangku kepentingan, model hubungan pemangku kepentingan, era masyarakat digital.

Managing stakeholders in the era of digital society become more complicated and the corporate crisis is highly potential to come forward. Consequently, to develop a long-term profitable relationship with the stakeholders requires dialogue based method. However, many corporate implement stakeholder relationship model remain derived from the understanding that corporate is the centre of all stakeholders, or corporate-centric model. A new model of system-centric than proposed in order to deal with the stakeholders in the era of digital society. The model implies that the corporate will be no longer being a central of stakeholders. It means the position of the corporate being a part of the system and involve symmetrical two-way communication strategy. This paper aimed at, firstly to elaborate a social network that would be potential to create the crisis if the corporate is not implementing the system-centric model that requires the development of multi-stakeholders learning dialogues. Secondly, it also analyzed the steps should be taken into account in order to transform traditional model toward symmetrical communication model of stakeholder relationship. Furthermore, method of literature review was applied as a basis of theoretical construction on stakeholder relationship model that should be engaged in avoiding of the crisis.
Keywords: Corporate crisis, stake holder, stakeholder relationship model, digital society era. 


\section{PENDAHULUAN}

Pesatnya perkembangan teknologi informasi telah menciptakan sebuah dunia tanpa batas, a borderless world, di mana teknologi digital dan internet memainkan peran penting dalam mengubah peradaban manusia menjadi semakin kompleks (Estaswara, 2008a). Faktanya, perubahan teknologi komunikasi dari sistem analog menjadi digital menjadikan media komunikasi yang berbasis internet berkembang pesat selama hampir tiga dekade terakhir.

Hal ini membuat interaksi dan sharing informasi yang terjadi secara mondial, semakin beragam, dinamis, dan juga cepat (Eid \& Ward, 2009; Jordan, et al., 2003; Mantovani, 2001). Aktoraktor komunikasi yang berinteraksi dan melakukan sharing informasi pun tidak sebatas organisasi atau perusahaan, namun juga komunitas dan melibatkan semua jenis komunikator, termasuk individuindividu (Eid \& Ward, 2009; Mantovani, 2001).

Di era mass communication (komunikasi massa) yang bersifat satu arah (one-way) dan linear, media massa menjadi mainstream media. Namun demikian, tidak semua orang dapat mengakses media massa dan mengomunikasikan kepentingannya. Masyarakat massa umumnya hanya sebagai penonton, pendengar dan pembaca atau hanyalah penerima pesan (komunikan pasif) tanpa bisa mengomentari (memberikan feed back) informasi tersebut secara langsung kepada senderapalagi komentarnya bisa dimuat di media massa.

Hanya pihak-pihak tertentu saja yang memiliki popularitas sosial, kekuasaan politik, atau kemampuan finansial yang mampu mengakses media massa untuk mendapatkan publikasi luas. Salah satu aktor komunikasi utama di era mass communication adalah perusahaan. Perusahaan gencar menginformasikan produk atau mereknya melalui iklan media massa dengan anggaran miliaran rupiah demi penciptaan profitabilitas. Tidak hanya itu, dengan strategi dan kegiatan media relations yang efektif, perusahaan juga memeroleh "publikasi gratis" dengan berita yang positif guna membangun image dan reputasinya.

Situasi seperti ini kemudian berubah di era digital. Perusahaan bukan lagi menjadi satu-satunya pihak yang memiliki kuasa dalam pengelolaan media dan informasi (Fill, 2006). Perusahaan juga bukan lagi aktor utama yang bisa mengontrol komunikasi melalui media demi menciptakan nama baik dan meningkatkan reputasi sehingga akumulasi profit, pembangunan merek dan penjualan produknya tetap terkelola secara menguntungkan. Teknologi media telah berubah dan aktor-aktor komunikasi pun telah meluas sampai pada tataran personal. Akibat dari kondisi ini, informasi mengenai krisis, isu-isu miring, dan beritaberita negatif yang terkait dengan perusahaan sangat berpotensi besar menyebar dengan cepat (Rajasekera, 2010), yang bisa dilakukan oleh siapa saja, dari mana pun dia berada dan kapan saja.

Beberapa perusahaan bahkan pernah mengalami krisis akibat dari berbagai isu negatif yang menyebar via Internet, seperti yang dialami oleh Dell pada tahun 2005 (Market Sentinel, 2007) yang terkenal dengan kasus "Dell Hell", kemudian RS Omni Internasional mengalami hal yang sama di tahun 2009 (Ardani, 2010; Estaswara, 2011a). Kedua kasus tersebut di atas memiliki kesamaan penyebab krisis yang bermula hanya dari ketidakpuasan satu orang konsumen atas pelayanan perusahaan. Tidak hanya itu, perusahaan sekelas Toyota pun-perusahaan otomotif terbesar di dunia yang menerapkan Total Quality Management (TQM)-juga mengalami krisis terkait dengan masalah keamanan yang berakibat pada penarikan produknya yang mencapai hampir tiga juta unit hanya di Amerika Serikat (AS) saja pada awal tahun 2010 (Rajasekera, 2010).

Terkait dengan krisis perusahaan di era digital, Fearn-Banks (2009:741) pernah mengatakan bahwa, "all companies, organizations, and individuals who depend on image and/or reputation to be successful should always accept the fact that they are always in a stage of crisis." Lebih menarik lagi jika mencermati pernyataan Lerbinger (Heath \& O'Hair, 2009:40), bahwa, "incidence and severity of crisis is rising with the complexity of technology and society." Kenyataannya, seiring perkembangan internet dan berbagai teknologi media komunikasi digital yang dapat diakses secara personal kapan pun dan dari mana pun juga, membuat masyarakat memiliki kekuasaan untuk menghindari pesanpesan perusahaan (Magnani, 2004). Lebih jauh lagi, hari ini masyarakat bahkan memiliki kuasa atas media komunikasi yang digunakannya, sehingga mereka bisa menyampaikan opini, sikap dan tindakannya tentang apa pun dan kepada siapa pun, termasuk tentang perusahaan, produk dan mereknya.

Bagaimana pun juga kompleksitas teknologi dan masyarakat telah melahirkan peradaban baru yang dikenal dengan era digital society. Akibatnya, 
pemahaman tentang krisis dan resiko yang harus dihadapi perusahaan menjadi krusial (Heath \& O'Hair, 2009). Apalagi dengan hadirnya teknologi Web 2.0, di mana media jejaring sosial, seperti Facebook, MySpace, Twitter, Instagram, Line dan sebagainya telah memungkinkan terjadinya komunikasi yang bersifat dua arah secara simetris (two-way symetrical communication)-lebih dari itu, juga bersifat segala arah (many-way communication) melalui social cyber group yang berbasis community building-secara real time (McLoughlin \& Lee, 2008; Mantovani, 2001).

Akhirnya, pemikiran tentang komunikasi sebagai transaksi (West \& Turner, 2007) yang bersifat symmetrical dan dilakukan melalui Computer-Mediated Communication (CMC) menjadi penting dalam memahami berbagai potensi krisis yang dihadapi perusahaan di era digital dewasa ini. Konsekuensinya, karakteristik hubungan dan cara berkomunikasi telah berubah sehingga pembangunan hubungan jangka panjang yang saling menguntungkan antara perusahaan dengan para stakeholders-nya menjadi semakin kompleks di banding dengan masa lalu. Kompleksitas ini dipicu dengan adanya penyebaran aktor pemilik otoritas atas informasi dan penguasaan media komunikasi.

Dari pemahaman ini, lahir pertanyaanpertanyaan lanjutan, seperti apakah model hubungan dengan stakeholder yang dipraktekkan di era-era sebelumnya masih relevan sampai hari ini ataukah dibutuhkan adanya berbagai penyesuaian atau bahkan diperlukan perubahan model hubungan terkait dengan besarnya potensi krisis dan resiko yang dihadapi perusahaan? Jika ternyata diperlukan adanya perubahan model, pertanyaannya kemudian bagaimana proses perubahan tersebut harus dijalankan oleh perusahaan? Berangkat dari uraian di atas, maka artikel ini bertujuan untuk menjawab tentang dua hal, yaitu: (1) Bagaimana model stakeholder relations yang harus diimplementasikan oleh perusahaan dalam merespons kompleksitas sistem di era digital sehingga mampu mengelola krisis secara tepat? (2) Bagaimana pula tahaptahap transformasinya sehingga perusahaan bisa mengimplementasikan model stakeholder relations tersebut?

\section{TINJAUAN PUSTAKA}

\section{Era Masyarakat Digital}

Peran internet melalui Social Networking Site (SNSs) atau media jejaring sosial, seperti Facebook, Twitter dan sebagainya-yang telah menciptakan ruang publik atau public sphere (Estaswara, 2011b) sebagai bentuk "cyber democracy" dan memiliki kapasitas untuk menyebarluaskan pesan secara real time-dewasa ini menjadi sangat penting dalam kehidupan manusia (Owen \& Humphrey, 2008). Semua sepakat bahwa hari ini SNSs telah menjadi fenomena global (Vilpponen, et. al., 2006; De Bruyn \& Lilien, 2008; Gangadharbatla, 2008). Ribuan bahkan jutaan manusia di seluruh dunia telah menggunakan Blog, Facebook, MySpace, Twitter, WhatsApp, Skype, Instagram, Line dan berbagai media sosial lain yang serupa sebagai media komunikasi.

Tidak hanya itu, juga terhubung secara mobile melalui smartphone dan menjadikannya sebagai aktivitas harian yang signifikan (Boyd \& Ellison, 2008). SNSs juga membantu untuk menjalin kembali hubungan dengan teman lamanya atau menjadi sarana untuk membangun hubungan dengan teman baru di seluruh dunia, tanpa batas waktu dan geografis. Di media ini, manusia telah membentuk komunitas-komunitas online sesuai dengan hobby, interest, serta concern-nya masing-masing (Parks \& Floyd, 1996).

Lahirnya media baru (new media) dan SNSs, bagaimana pun juga telah mempermudah manusia dalam berkomunikasi dan berinteraksi. Majunya teknologi internet bahkan telah melahirkan ratusan SNSs dengan berbagai dinamika dan kompleksitas yang ditinggalkannya. Menurut Byot dan Ellison (2008:211), SNSs sendiri didefinisikan sebagai berikut:

"Web-based services that allow individuals to (1) construct a public or semi-public profile within a bounded system, (2) articulate a list of other users with whom they share a connection, and (3) view and traverse their list of connections and those made by others within the system. The nature and nomenclature of these connections may vary from site to site."

SNSs dapat dikatakan unik karena para penggunanya dapat membuat jaringan sosial mereka sendiri serta berkomunikasi dengan orang yang sudah menjadi bagian dari SNSs 
tersebut. Aktivitas ini memang belum tentu dapat menciptakan hubungan antar individu secara real seperti layaknya dalam kehidupan nyata, namun yang sering terjadi adalah terciptanya "hubungan laten," di mana para user bertemu secara online untuk saling berbagi (Byot \& Ellison, 2008). Daya tarik dari aplikasi SNSs adalah kemampuannya dalam memenuhi rasa ingin tahu para penggunanya tentang orang lain dan apa saja yang sedang mereka lakukan dengan kehidupannya. Di samping memperoleh dan membagi informasi (HennigThurau et al., 2004), juga terdapat keinginan untuk mempelajari dan menjalin hubungan dengan orang lain, baik yang dikenal maupun tidak, yang dapat dimanfaatkan pula untuk memerkuat kegiatan offline-nya.

Konsep "Social Network Sites" sebenarnya lebih tepat digunakan untuk mendeskripsikan fenomena masyarakat digital dari pada "networking" (jaringan). Hal ini mengingat juga bahwa makna SNSs tidak hanya sebatas pada "networking" semata, namun juga mengandung pengertian tentang public discourse (ruang publik) di mana keduanya dapat saling dipertukarkan. Pengertian "networking" atau jaringan sendiri lebih menekankan pada persoalan pembangunan hubungan, termasuk dengan orang asing. Walaupun pembentukan jaringan pertemananyang di dalamnya terkandung juga makna jaringan komunikasi-dapat dilakukan di situs-situs tersebut, namun hal ini bukanlah tujuan utamanya.

Di samping itu, "networking" juga bukan hal yang dapat dibedakan dari berbagai bentuk komunikasi dalam konteks CMC lainnya. Mengapa demikian? Bukan sekedar karena kemampuan media yang memberikan akses jaringan komunikasi, namun kualitas dan kompleksitas dinamika komunikasi yang terbentuk sebagai konsekuensi logis dari ruang diskusi publik tanpa batas dan bahkan sering kali tanpa aturan inilah yang menjadi perhatian penting. SNSs merupakan sebuah ruang imajiner di mana setiap orang dapat berbicara dan melakukan apa saja layaknya dalam kehidupan sosial sehari-hari dengan cara baru. Dengan demikian, jaringan sosial yang terbentuk melalui SNSs dengan basis teknologi digital serta dinamika komunikasi yang terjadi dapat dikatakan telah melahirkan sebuah era baru, yang dapat dikatakan sebagai era digital society (masyarakat digital).

\section{Krisis Perusahaan}

Di era masyarakat digital, Internet secara dramatis telah memfasilitasi hubungan antar manusia dan menggeser kekuasaan komunikasi berada di tangan para user, alih-alih institusi atau organisasi (Craig, 2007). Interkonektivitas ini telah menjadi fenomena global yang memfasilitasi penyebaran words-of-mouth (WOM), baik informasi-informasi yang bersifat positif maupun negatif (Shankar at al., 2003). Sebuah data menunjukkan terdapat lebih dari 150 juta blog, jaringan sosial, situs opini konsumen, video dan picture sharing networks, serta worldwide message boards (Bell, 2007). Akibatnya, penyebaran informasi melalui media komunikasi online yang berjumlah sangat banyak tersebut bagaimana pun juga tidak mudah dikendalikan oleh perusahaan (Bruyn \& Lilien, 2008). Tidak hanya itu, bahkan berpotensi besar menjadi sumber krisis (Hallahan, 2009). Berbagai fakta di atas akhirnya membuat Internet melalui SNSs telah mengubah cara pandang para praktisi perusahaan, konsultan komunikasi dan tentunya juga para akademisi, dalam memahami krisis dan bagaimana cara mengelolanya (Calloway \& Keen, 1996).

Menurut Fearn-Banks (1996:1) krisis dimaknai sebagai: "a major occurrence with a potentially negative outcome affecting an organization, company or industry, as well as its publics, products, services or good name." Artinya, krisis terjadi jika ada kejadian besar yang bersifat negatif dan berpotensi mempengaruhi kepentingan perusahaan atau industrinya, yang pada akhirnya bisa berakibat buruk terhadap penjualan barang dan jasa yang ditawarkannya dan berdampak pula pada citra dan reputasi perusahaan. Tidak hanya itu, krisis bisa muncul jika kejadian negatif tersebut juga berpotensi untuk mempengaruhi publiknya, sehingga mampu mengubah opini, sikap dan bahkan tindakan publik tentang perusahaan. Selaras dengan gagasan tersebut, Shrivasta dan Mitroff (1987:6) mendeskripsikan krisis perusahaan sebagai: "events that threaten most important goals of survival and profitability." Di samping itu, krisis juga bisa terjadi jika ada peristiwa-peristiwa yang mengancam tujuan terpenting dari kelangsungan hidup dan profitabilitas perusahaan.

Krisis pada dasarnya merupakan persoalan komunikasi. Hal ini mengingat bahwa inti dari komunikasi adalah persepsi (Estaswara, 2008b), maka krisis komunikasi pada dasarnya adalah persoalan persepsi. Selaras dengan pemikiran ini, 
Coombs (2009:99) mendefinisikan krisis sebagai berikut: "perception of an event that threatens important expectancies of stakeholders and can impact the organization's performance." Artinya, krisis merupakan persepsi dari suatu peristiwa yang mengancam harapan-harapan dari para stakeholder dan dapat mempengaruhi kinerja organisasi. Dengan demikian, jika para stakeholder percaya telah terjadi krisis, artinya perusahaan 'memang' berada dalam situasi krisis. Krisis dapat ditangani jika perusahaan tersebut benar-benar mampu meyakinkan kepada stakeholder-nya bahwa sebenarnya tidak ada krisis. Di sisi lain, krisis juga terkait dengan masalah expectations. Krisis terjadi jika harapan dari para stakeholders tidak sesuai dengan kenyataan yang dilakukan dan/atau yang diberikan oleh perusahaan (Coombs, 2009).

Krisis komunikasi di perusahaan dapat dideskripsikan juga dengan analogi gunung es, di mana hanya ada seperdelapan bagian yang muncul ke permukaan. Bagian yang terlihat tersebut adalah public words dan tindakan perusahan sebagai responsnya terhadap krisis (Coombs, 2009). Sedangkan sisanya merupakan sebuah "ruang gelap" (black box) yang seringkali tidak diperhatikan atau susah diidentifikasi. Logika berpikir inilah yang mendasari alasan mengapa penelitian tentang krisis komunikasi dari berbagai sudut pandang masih tetap relevan sampai hari ini (Hallahan, 2009; Coombs, 2006).

Secara umum, krisis perusahaan merupakan gabungan dari dua proses komunikasi, yaitu crisis knowledge management dan stakeholder reaction management (Coombs, 2009) Artinya, pemahaman atas situasi pada dasarnya akan memberikan pengetahuan yang tepat bagi manajemen, sehingga dapat digunakan sebagai dasar pengambilan keputusan terkait dengan bagaimana cara berkomunikasi yang harus dilakukan oleh perusahaan dan apa content informasi yang perlu disampaikan sebagai jawaban atas reaksi stakeholders terhadap isu-isu yang memiliki potensi melahirkan krisis (Coombs, 2009). Rangkaian proses di atas merupakan tahapan pra-krisis yang menjadi tahapan paling menentukan bagi perusahaan dalam crisis management.

Jika dilihat melalui pemikiran Fearn-Banks (2009), tahap ini disebut dengan tahap "detection" dan "prevention dan/atau preparation." Tahap detection merupakan proses monitoring secara terus-menerus terhadap tanda-tanda krisis yang mungkin ada. Sedangkan tahap prevention adalah tahap di mana perusahaan mengambil langkahlangkah pencegahan untuk menghindari terjadinya krisis-seperti kata pepatah, memadamkan api sebelum terjadi kebakaran. Prevention sangat berhubungan erat dengan masalah preparation atau perencanaan (planning) tentang bagaimana perusahaan akan mengatasi krisis jika krisis tersebut benar-benar terjadi. Maka tidaklah mengherankan jika banyak perusahaan melakukan penelitian guna memahami dan memonitor kondisi lingkungan melalui beberapa riset, seperi environmental monitoring atau assessment program, public relations audit sampai communication audit. Tujuannya adalah untuk memastikan apakah ada tanda-tanda krisis yang akan mengancam perusahaan.

\section{Stakeholder}

Sebelum lebih jauh mendiskusikan persoalan krisis perusahaan, penting kiranya untuk memahami apa yang dimaksud dengan stakeholder dan apa pula bedanya dengan publik. Memang, pada umumnya kata "publik" sering dipertukarkan dengan "stakeholder," namun kedua kata tersebut sebenarnya memiliki makna yang berbeda. Stakeholder merupakan bagian dari publik, namun demikian publik belum tentu stakeholder. Pemahaman ini berbeda dengan pengertian tentang significant public yang dapat dipertukarkan dengan stakeholder. Secara umum, publik didefinisikan sebagai "any group whose members have a common interest or common values in particular situation" (Guth \& Marsh, 2003:91). Sebagai contoh, mulai kelompok pecinta mobil seperti $\mathrm{MBCl}$ (Mercedes-Benz Boxer Club Indonesia), partai politik, LSM, organisasi mahasiswa, sampai perkumpulan petani, semua kelompok tersebut dapat dikatakan sebagai publik. Di Indonesia, seperti halnya di AS (Guth \& Marsh, 2003:92), menghitung jumlah publik seperti menghitung banyaknya bintang di langit, atau suatu pekerjaan yang mustahil dilakukan, mengingat banyaknya kelompok yang dapat didefinisikan sebagai publik.

Lebih lanjut, stakeholder sendiri dapat diartikan sebagai individu atau organisasi-baik bersifat profit maupun bukan-yang memiliki kepentingan dengan perusahaan sehingga dapat mempengaruhi atau dipengaruhi oleh pencapaian tujuan dan kelangsungan hidup perusahaan (Guth \& Marsh, 2003; Preston, \& Sapienza, 1990). Walaupun definisi stakeholder di atas terkesan hanya berfokus pada perusahaan, tetapi pengertiannya secara 
umum sebenarnya selaras dengan pemahaman yang pernah diajukan oleh Freeman (1984:25)yang sampai saat ini banyak dikutip oleh para akademisi-(Morsing \& Schultz, 2006:324; Lozano, 2008), sebagai berikut: "Any group or individual who can affect or is affected by the achievement of the firm's objectives." Di sisi lain, Guth \& Marsh (2003:7) mengatakannya dengan: "when a public has a relationship with your organization, the public is called a stakeholder, meaning that it has a stake in your organization or in an issue potentially involveving your organization."

Didirikannya suatu perusahaan pasti memiliki tujuan, yang umumnya tercermin dari visi dan misi korporat. Dalam mencapai tujuannya tersebut, setiap perusahaan harus menjalin kerjasama yang saling menguntungkan dalam jangka panjang dengan pihak-pihak lain sehingga kinerja mata rantai bisnisnya tetap tinggi dan jaringan strategisnya tetap terjaga dengan baik (Werther \& Chandler, 2006). Faktanya, tidak ada satu pun perusahaan di dunia ini yang dapat hidup dalam ruang hampa sosial, karena tidak ada satu perusahaan pun yang dapat mencapai tujuannya tanpa berhubungan dengan dan mendapatkan bantuan (support) dari pihak-pihak lain, seperti karyawan, pemegang saham, pelanggan, pemasok, distributor, regulator, lembaga keuangan, media massa, pemerintah, sampai komunitas-komunitas tertentu. Berdasarkan uraian tersebut, jelaslah bahwa membangun hubungan baik dan saling menguntungkan melalui komunikasi dua arah yang bersifat sirkular dan simetris dengan stakeholder, penting artinya bagi perusahaan (D'Aveni, 1994; Grunig, \& Repper, 1992). Bahkan perannya dapat dikatakan sangat strategis, karena kegagalan dalam menjalin hubungan dengan stakeholder bisa mempengaruhi proses pencapaian tujuan perusahaan, yaitu penciptaan profit dalam jangka panjang.

Menurut Waldt (2004:134), "communication can ease the pain of change for organizations." Artinya, komunikasi bukanlah sekedar persoalan memberikan informasi dan fakta (cognitive based), tetapi juga harus mampu memberdayakan (affective based) para stakeholder-nya untuk memahami dan mendukung proses-proses pencapaian tujuan, arah perubahan, maupun transformasi yang sedang dialami oleh perusahaan. Jika para stakeholder dapat lebih mendengar dan belajar tentang mengapa dan bagaimana sebuah perusahaan bergerak ke arah tertentu, maka potensi terjadinya konflik antara stakeholder dengan pemahaman dan sikapnya tentang program-program dan prioritas perusahaan dapat diminimalisasi pada titik yang paling rendah. Namun, hal ini dapat dicapai jika perusahaan mau dan mampu untuk lebih mendengarkan, memperhatikan, memahami dan belajar dari stakeholder-nya. Dengan demikian, keputusankeputusan yang diambil oleh perusahaan akan lebih selaras dengan harapan, kebutuhan dan kepentingan dari para stakeholder (Kuchi, 2006; Da Saez, 2002). Walaupun demikian, perlunya untuk tetap memerhatikan prinsip-prinsip saling menghormati dan saling memahami antar pihakpihak yang terkait tanpa harus mengorbankan kualitas hubungan yang terjalin. Pada titik ini dibutuhkan komunikasi dua arah yang simetris sehingga terjadi learning dialogue antara perusahaan dengan para stakeholder-nya.

\section{Kompleksitas Hubungan Berpusat Pada Sistem}

Secara umum, sebenarnya organisasi mengenal krisis sejak jaman dahulu, ketika menyadari perlunya suksesi akibat kematian seorang pimpinan dan harus mencari pemimpin pengganti, baik akibat umur maupun peperangan antar suku. Dalam perkembangannya sampai saat ini, khususnya sejak tiga dekade terakhir, pemikiran tentang krisis telah berkembang pesat, termasuk dalam disiplin komunikasi yang sering dikenal dengan crisis communication (Gilpin \& Murphy, 2008).

Dalam dunia akademik, kata "krisis" awalnya berasal dari ilmu obat-obatan yang kemudian maknanya meluas dan diartikan sebagai, " $a$ relatively short period of confusion or turbulence which leads to a transition from one [state] to another" (Burke, 2000:203). Makna krisis sendiri pada dasarnya tidak selalu berarti buruk, mengutip Fink (1986), krisis memang bisa diartikan "danger" (buruk), namun juga berarti "opportunity" (baik). Banyak pemikir telah mengidentifikasi bentukbentuk krisis, salah satunya krisis bisa terbentuk karena informasi dan komunikasi akibat dari perkembangan teknologi media dan perubahan perilaku komunikasi (Mitroff, 2004; Mitroff \& Anagnos, 2001; Mitroff \& Pearson, 1993; Pauchant \& Mitroff, 1992).

Memahami krisis perusahaan di era masyarakat digital dapat dianalisis dari teori kompleksitas (complexity theory). Secara umum, teori kompleksitas dalam disiplin ilmu sosial menurut Murphy (2000:450) dikatakan sebagai, 
"the study of many individual actors who interact locally in an effort to adapt to their immediate situation. These local adaptations, however, accumulate to form large-scale patterns that affect the greater society, often in ways that could not have been anticipated." Gagasan ini sebenarnya selaras dengan teori sistem kompleks (complex system) di mana terdapat banyak entitas, kelompok atau komunitas yang saling berinteraksi secara non-linier (Richardson and Cilliers, 2001). Secara sederhana, ilmu ini dalam pandangan van Uden et al. (2001:57) dikatakan bahwa, "complexity science basically tells us that everything is connected to everything else." Dengan demikian, akibat dari perubahan teknologi media komunikasi dan perilaku masyarakat dewasa ini, pemahaman tentang krisis komunikasi dapat dijelaskan melalui kerangka teori sistem kompleks. Pemikiran seperti ini selaras dengan pandangan Lozano (2008) terkait dengan pengelolaan stakeholder yang menyatakan bahwa pandangan corporate centric sudah tidak relevan digunakan di era masyarakat digital. Perlunya untuk memahami komplekitas sistem guna menjelaskan model stakeholder relations di era jaringan, atau yang dikenal dengan system-centric. Berangkat dari gagasan tersebut, maka jelaslah bahwa perusahaan harus berubah dari corporatecentric menjadi system-centric guna mengantisipasi krisis di era digital media.

\section{METODE}

Tulisan ini menggunakan metode literature review sebagai basis dalam membangun teori dan analisis dengan cara mengaitkan berbagai konsep yang relevan dari berbagai sumber ilmiah terkait dengan stakaholder relations, masyarakat digital, media baru dan krisis perusahaan. Dengan demikian berbagai data sekunder yang berbentuk dokumen tertulis dan diperoleh dari studi pustaka digunakan dalam penelitian ini, seperti buku, jurnal ilmiah serta publikasi hasil penelitian lainnya. Jenis penelitian dalam tulisan ini adalah theoreticalanalytic yang bertujuan menggambarkan, menyimpulkan, mengevaluasi, mengklarifikasi, dan mengintegrasikan model pemikiran (Cooper, 1988; Randolph, 2009) yang terkait dengan stakeholder relations di era masyarakat digital dan bagaimana melakukan transformasi model tersebut dalam perusahaan.

\section{HASIL DAN PEMBAHASAN}

\section{Model Stakeholder Relationship di Era Digital Society}

Prinsip pembangunan hubungan dengan para stakeholder yang umumnya berkembang saat ini masih berbasis pada pemahaman bahwa perusahaan adalah pusat dari semua stakeholder atau yang sering dikenal sebagai pendekatan corporate-centric (Lozano, 2008). Paradigma ini ternyata masih dipegang teguh dan banyak dipraktekkan sampai hari ini oleh perusahaanperusahaan di dunia-termasuk juga perusahaanperusahaan di Indonesia. Pendekatan ini mengasumsikan bahwa perusahaan merupakan sentral (pusat) dari semua stakeholder-nya. Pemikiran seperti ini umumnya dipercaya sebagai sesuatu yang sudah demikian adanya (given), sehingga tidak perlu untuk dipertanyakan lagi. Maka, tidaklah mengherankan jika perusahaan tetap memegang teguh prinsip-prinsip dalam corporate-centric ini, mereka akan selalu mengalami masalah dalam membangun hubungan dengan para stakeholder-nya (Lozano, 2008) yang akhirnya krisis tidak dapat dihindari lagi. Konsepsi ini ibarat berulangnya kembali sejarah kesalahan pemikiran manusia. Sebelum abad pencerahan, pandangan yang dipercaya sebagai kebenaran adalah bumi merupakan pusat alam semesta. Padahal kita semua tahu bahwa pengetahuan seperti ini merupakan fakta yang salah.

Lozano (2008) menolak pemikiran tersebut dengan mengajukan konsep baru, system-centric. Prinsip stakeholder relations ini menyatakan bahwa perusahaan tidak lagi menjadi sentral (pusat) dari semua stakeholder-nya. Ibarat Copernicus yang datang memberikan pencerahan pengetahuan, fakta yang sebenarnya adalah bumi bukanlah pusat dari alam semesta. Demikian juga dengan perusahaan. Perusahaan bukanlah pusat dari semua stakeholder. Pertanyaannya kemudian, lalu siapa yang menjadi pusat dari hubungan antar stakeholder? Di mana posisi perusahaan yang sebenarnya dalam pendekatan stakeholder relations ini? Seperti yang dikatakan oleh Copernicus, bumi hanyalah bagian kecil dari sistem alam semesta, maka demikianlah seharusnya posisi perusahaan, menjadi bagian dari sistem di mana perusahaan tersebut berada, berinteraksi dan menjalankan bisnisnya (Lozano, 2008). 
Gambar 1. Model Corporate-Centric

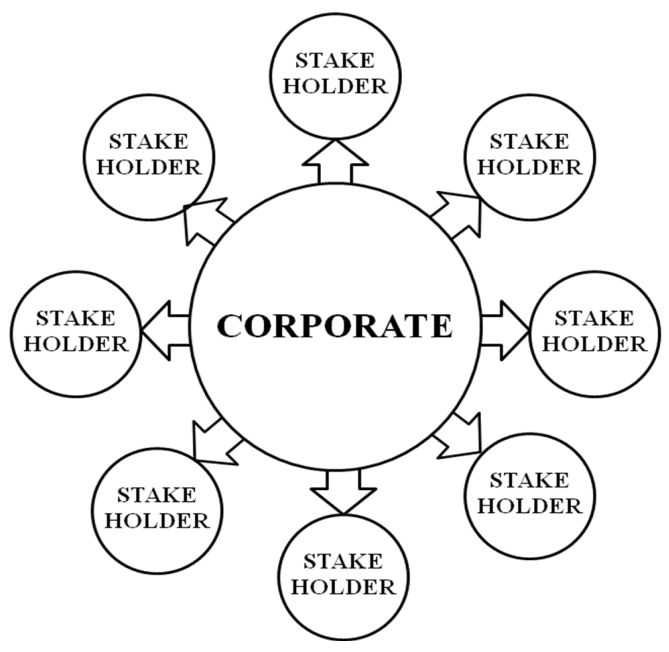

Sumber: Theorizing penulis yang diadaptasi dari Lozano (2008)

Model corporate centric sendiri dapat dikatakan sebagai pendekatan inside-out. Inside-out adalah bentuk a-priori perusahaan dalam mencapai tujuannya (Estaswara, 2008a). Perusahaan dengan semua kepentingannya mendefinisikan dan menentukan bagaimana model hubungan dengan para stakeholder-nya harus dibangun. Prinsipnya, hubungan dengan para stakeholder harus menyesuaikan dengan kebijakan perusahaan, di mana hubungan tersebut dikelola dan diatur guna mencapai tujuan perusahaan yang telah ditetapkan. Model ini menyiratkan sedikit perhatian terhadap pembangunan kualitas hubungan jangka panjang yang saling menguntungkan berdasarkan atas kesetaraan kedudukan dengan para stakeholdernya. Peran perusahaan dapat dikatakan sebagai "koordinator hubungan" (relationship coordinator) yang tugasnya hanya menjadi "penghubung" antara perusahaan dengan para stakeholdernya. Dalam konteks disiplin komunikasi, model corporate-centric ini umumnya menyiratkan perspektif one-way communication (linear model of communication). Namun, dalam kondisi krisis, komunikasi yang dilakukan oleh perusahaan dalam model ini hanyalah merepresentasikan pendekatan asymetric two-ways communication. Perusahaan berusaha mencari data dan fakta sebagai bentuk "feed back" dari para stakeholder melalui penelitian dalam upaya pencarian solusi atas krisis yang terjadi.

Dalam model ini, strategi hubungan yang dibangun relatif sederhana atau dapat juga dikatakan dengan speak with one voice. The voice of the company's interest. Satu strategi dan kepentingan satu pihak-yaitu kepentingan pihak perusahaan itu sendiri-yang menjadi dasar dalam menjalin hubungan dengan semua stakeholder. Jika sebuah perusahaan masih menganut model stakeholder relations yang bersifat tradisional ini, maka dapat dikatakan bahwa pembangunan hubungan dengan para stakeholder-nya-tidak masalah sejauhmana tingkat efektivitasnya-akan selalu ditentukan oleh dominasi dan pengawasan perusahaan (Estaswara, 2008a). Prinsip-prinsip yang dibangun bukanlah untuk menjalin hubungan yang "saling menguntungkan" namun hanya akan terbentuk hubungan yang "menguntungkan perusahaan". Karakter hubungan seperti ini umumnya sangat rentan terkait dengan waktu. Artinya, tidak dapat digunakan sebagai dasar dalam menjalin hubungan jangka panjang.

Di era digital society, maraknya SNSs melalui internet telah menciptakan mobilisasi informasi yang tinggi dan melahirkan apa yang dikenal dengan "citizen journalism" (Fearn-Banks, 2009). Di sisi lain, meminjam pemikiran Harbermas (1974) tentang public sphere, internet dan SNSs juga dikatakan telah menciptakan fenomena "computer-mediated public sphere" (Estaswara, 2011b). Sedangkan menurut Beck (Lozano, 2008), salah satu sisi gelap globalisasi dan internet adalah lahirnya masyarakat risiko. Dalam masyarakat ini, ancaman tidak datang dari fenomena alam yang merusak, namun muncul akibat dari tindakan komunikasi manusia dengan semua kepentingannya, termasuk di dalamnya motif atas pengetahuan dan ekonomi, yang direpresentasikan melalui SNSs. Dengan demikian, perusahaan modern bagaimana pun juga tidak bisa lagi mengasumsikan bahwa posisinya berada di pusat (sentral) dari para stakeholder atau masih mengimplementasikan model corporate-centric di era masayarakt digital.

Merespons perkembangan teknologi komunikasi dan munculnya digital society, model system-centric lebih tepat diimplementasikan, baik dengan tujuan untuk menjaga stabilitas perusahaan ataupun untuk meminimalisasi resiko krisis yang harus dihadapi. Posisi perusahaan dalam pendekatan sistem pada dasarnya tidak selalu berada di pusat, namun lebih fleksibel dan dinamis, bisa berada di mana pun juga dan rentan bergeser ke segala arah. Sebagai konsekuensinya, perusahaan harus mampu memahami secara komprehensif bagaimana pola-pola interaksi yang terjadi di antara para stakeholder dalam kompleksitas sistem jejaring sosial 
dan menentukan posisinya secara tepat dalam sistem jejaring tersebut.

Kemampuan dalam mengidentifikasikan posisi perusahaan sangat menentukan bagaimana strategi komunikasi harus ditetapkan dalam kaitannya untuk membangun hubungan jangka panjang yang saling menguntungkan dengan para stakeholdernya. Kesalahan dalam mengidentifikasi posisi perusahaan dalam kompleksitas sistem jejaring sosial yang terbentuk oleh internet bisa menjadi awal dari lahirnya krisis. Lebih buruk lagi, akan berdampak pada kegagalan dalam mencapai tujuannya (Rowley, 1997). Secara umum, inti pemikiran ini adalah social network complexity (Mitchell et al., 1997; Estaswara, 2011a).

Internet serta komputer dan handphone "harus" bertanggungjawab penuh terhadap "datarnya dunia" yang menyebabkan kompetisi pasar menjadi semakin tinggi, terjadinya perubahan atas selera konsumen, dan membuat lingkungan bisnis menjadi sangat dinamis dan sulit diprediksi (unpredictable). Keberadaannya sudah secara terang-terangan menantang eksistensi perusahaan. Konsekuensinya, perusahaan harus mampu merespons secara cepat berbagai berubahan lingkungan tersebut (Estaswara, 2008a), yang artinya pula, perusahaan harus mampu mengikuti kompleksitas dinamika sistem sosial yang terbentuk via internet.

Dalam kondisi seperti ini, perusahaan tidak bisa secara mutlak dipandang sebagai pusat dari stakeholer-nya, namun merupakan bagian dari kompleksitas sistem yang terbentuk. Contoh menarik terkait dengan kesalahan dalam pengimplementasian model stakeholder relations oleh perusahaan di Indonesia adalah kasus Rumah Sakit Omni International pada tahun 2009 (Ardani, 2010; Estaswara, 2011a). Di era digital society yang unpredictable dewasa ini, perusahaan tidak dapat melihat hubungan dengan para stakeholder-nya hanya melalui kacamatanya sendiri.

Arogansi perusahaan bisa bertentangan dengan opini publik yang terbentuk melalui jejaring sosial. Kasus Prita melawan RS Omni International telah membuktikan bahwa SNSs bisa menciptakan krisis dan akhirnya mempengaruhi kepentingan dan tujuan utama dari perusahaan. Kasus ini merupakan bukti atas kapasitas Facebook dalam menciptakan dukungan masyarakat yang dapat menghancurkan reputasi perusahaan (detikNews, 02/06/2009, Ardani, 2010). Perusahaan bisa terseret ke dalam krisis hanya karena kesalahan dalam mengidentifikasi posisinya dengan para stakeholder, termasuk dengan Prita, sang pelanggan.

Berbicara mengenai sistem, teorinya memiliki akar yang kompleks, tapi pemikiran yang relevan untuk teori stakeholder relations telah dirintis oleh Ackoff dan Churchman (Lozano, 2008). Teori sistem pada dasarnya menekankan bahwa hubungan eksternal merupakan bagian dari setiap organisasi. Dengan demikian, dalam konteks tulisan ini, organisasi dapat digambarkan sebagai sebuah "sistem terbuka" yang menjadi bagian dari jaringan yang jauh lebih besar dan kompleks di era digital society hari ini alih-alih sebagai suatu entitas yang berdiri sendiri. Identifikasi, baik atas stakeholder dan hubungan yang terjadi antar stakeholder dalam sistem tersebut, merupakan fokus dari pemikiran dalam model ini.

Gambar 2.

Model System-Centric

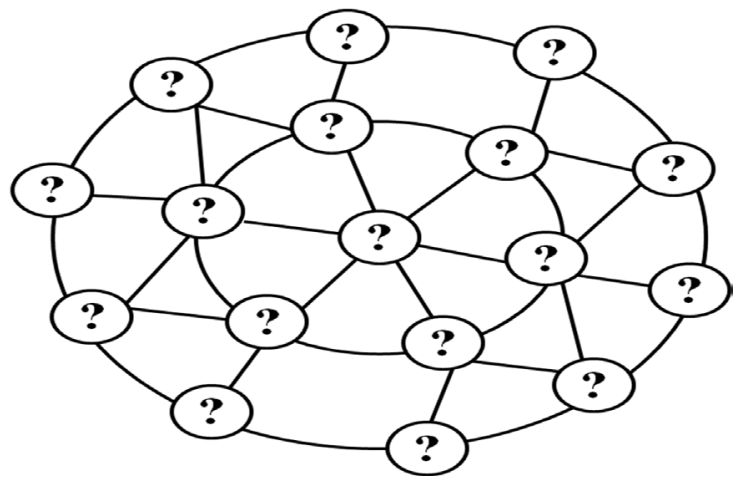

Sumber: Theorizing penulis yang diadaptasi dari Lozano (2008)

Ada tiga isu utama yang harus diperhatikan terkait dengan perusahaan sebagai subsistem dari kompleksitas sistem eksternal dalam konteks stakeholder relations. Pertama, perusahaan sebagai suatu sistem berarti perusahaan harus memiliki dukungan penuh dari subsistemnya agar aktivitasnya tetap berjalan dengan baik dan kinerja bisnisnya tetap terjaga. Subsistem dalam konteks ini bukan hanya bagian-bagian atau departemendepartemen dalam perusahaan, melainkan internal stakeholder yang menjadi driver (pendorong) utama dari berjalannya sistem organisasi. Pemahaman di atas menunjukkan bahwa membangun hubungan dengan internal stakeholder sangat penting bagi berlangsungnya kinerja operasi dari sistem perusahaan. Kedua, masalah menjadi lebih kompleks karena tidak hanya perusahaan saja yang memiliki hubungan dengan sistem yang lebih besar-sistem eksternal/sosial yang terbentuk di era informasi-namun para internal stakeholder-nya, dalam hal ini adalah karyawannya, 
juga terhubung melalui Internet yang memiliki kapasitas besar dalam penciptaan ruang publik (Estaswara, 2011b:108). Ketiga, posisi perusahaan sebagai sebuah sistem yang secara bersamaan juga menjadi subsistem dari sistem yang lebih besar, membuat perusahaan akan selalu terkait dengan lingkungan internal (subsistem dalam organisasi) dan lingkungan eksternal (perusahaan sebagai subsistem) dalam waktu yang sama.

Dari sudut pandang sistem, masalah hanya dapat diselesaikan jika ada dukungan dari semua anggota, dalam konteks ini adalah stakeholder, baik yang berasal dari lingkungan internal maupun eksternal, dalam jaringan tersebut. Teori sistem menekankan pengembangan strategi kolektif yang dimaksimalkan melalui jaringan. Strategi tunggal (baca: satu pihak) bukan menjadi fokus analisis dalam pendekatan ini. Strategi tunggal tidak akan menghasilkan solusi dalam pembangunan hubungan dengan stakeholder di dalam kompleksitas sistem. Kunci untuk memahami organisasi dewasa ini adalah konsep jaringan. Posisi organisasi berada dalam jaringan, tidak lagi di pusat, karena jaringan seringkali tidak didefinisikan dari pusat (Lozano, 2008). Ini berarti bahwa hubungan dengan stakeholder tidak dapat dilihat sebagai hubungan yang terpisah (segregated) atau dyadic (satu-lawan-satu atau one-to-one).

Pertanyaan yang muncul kemudian adalah, dalam system-centric, mungkinkah perusahaan tetap berada di pusat (center) dari stakeholdernya? Jawabannya adalah mungkin. Namun, hanya perusahaan-perusahaan yang memiliki reputasi yang unggul saja yang tetap mampu bertahan di posisi pusat dalam model system-centric. Hal ini karena hanya perusahaan-perusahaan yang memiliki reputasi baik-yang secara umum dapat dilihat dari kuatnya corporate image, tingginya corporate brand equity, sampai pelaksanaan Corporate Social Responssibility (CSR) atau corporate citizenship yang berkesinambunganyang memiliki kemampuan menjadi agen-agen perubahan sosial. Perusahaan-perusahaan tersebut bukanlah berada di pusat perubahan sosial, namun mereka adalah perubahan itu sendiri. Mereka-mereka adalah leader of thought. Menjadi pemimpin melalui ide-ide atau gagasan yang mampu menginspirasi masyarakat. Tidak hanya itu, mereka-mereka juga merupakan perusahaan yang concern dan mampu menjaga lingkungan hidup, "green corporate." Artinya, dengan kemampuan perusahaan untuk selalu proaktif dalam merespons berbagai dinamika isu global dan berperan aktif di dalamnya, logikanya perusahaan tersebut akan selalu berada dalam pusat perubahan sosial dan menjadi social change driver. Sehingga, perusahaan dapat mempertahankan posisinya sebagai pusat di antara para stakeholder-nya dalam kompleksitas sistem jaringan sosial di era digital society.

Dalam konteks hubungan, untuk bisa menjadi public-centric, sebuah perusahaan harus mampu memaksimalkan fungsi kecerdasannya. Suatu kecerdasan kolektif yang terstruktur dalam perusahaan yang dibangun dengan budaya organisasi yang unggul, yang terbentuk dari nilainilai dasar yang superior, semangat kerja yang tinggi, dan sumber daya manusia yang berkualitas (Ströh \& Jaatinen, 2001). Sebagai contoh, Mercedes Benz sebagai produser mobil yang menjual "kemewahan, eleganitas dan status sosial" memahami benar arti jualannya dan seperti apa makna produknya yang terbentuk dalam kehidupan masyarakat, tanpa harus meninggalkan tradisi atas penemuan-penemuan baru yang mampu mewarnai perubahan dunia dalam hal teknologi mesin, desain dan kompleksitas fitur-fitur yang melekat lainnya. Sehingga, Mercedes Benz mampu mendefinisikan makna kehidupan masyarakat dalam kelas dan gaya hidup tertentu alih-alih sebagai alat transportasi yang nyaman. Inilah yang membuat Mercedes Benz adalah trend setter. Trend setter bagaimana pun juga pasti bersifat public-centric. Namun, sebuah perusahaan bisa menjadi trend setter haruslah mendapat penerimaan publik terlebih dahulu. Inilah fungsi brand, image dan reputasi yang unggul dari sebuah perusahaan. Untuk mampu menciptakan perusahaan seperti ini, maka pentingnya learning dialogue antara perusahaan dan para stakeholdernya-multi-stakeholders learning dialogues (Lozano, 2008)-yang berbasis pada model hubungan system-centric dengan menekankan prinsip twoway symmetrical communication.

\section{Proses Transformasi Model Stakeholder Relationship}

Berangkat dari penjelasan di atas, di era digital society hari ini, bagaimana pun juga perusahaan harus berani mengubah model hubungannya dengan para stakeholder. Perusahaan harus mau meninggalkan cara-cara lama dan menstransformasi organisasinya dengan model hubungan yang sesuai ( $f i t$ ) dengan perubahan jaman. Walaupun demikian, perubahan model stakeholder relations dari corporate-centric menuju system-centric 
pada dasarnya bukan suatu pekerjaan yang mudah dan bukan hajatan dari satu departemen atau satu bagian saja dalam perusahaan-yang menurut Kauter et al. (Ströh \& Jaatinen, 2001:149) dikatakan sebagai, "the shift in behaviour of the whole organisation, to one degree or another." Perubahan ini sangat membutuhkan komitmen dari seluruh anggota perusahaan. Mengapa demikian? Karena system-centric pada dasarnya merupakan model stakeholder relationship yang terbuka dan transparan yang didasarkan pada pola-pola hubungan yang terbentuk dalam kompleksitas sistem, baik internal maupun eksternal perusahaan.

Perubahan atas model hubungan dengan stakeholder pada dasarnya juga mencerminkan transformasi organisasi. Sebuah perubahan paradigma dari pendekatan perusahaan yang bersifat tradisional menjadi perusahaan modern yang memiliki kapasitas sustainability di era digital society. Di samping itu, dapat diartikan juga sebagai perubahan dari perusahaan yang berorientasi pada fungsi (descriptive approach) menjadi perusahaan yang berorientasi pada tujuan (instrumental approach). Mengutip Damak-Ayadi \& Pesqueux (2005:149), transformasi organisasi atau perusahaan dikatakan sebagai, "step-by-step process of restructuring an existing organisationremoving what does not work, keeping that which does, and implementing new systems, structures, or cultural values where appropriate." Secara umum, mentransformasi model stakeholder relationship membutuhkan dua fase dan tiga tahap perubahan. Dua fase perubahan yang harus dilalui adalah fase inside-out dan outside-in. Sedangkan tiga tahap perubahan yang harus dilakukan dalam dua fase tersebut adalah: Tahap (1) Penguatan Fungsi (Function Reinforcement); (2) Identifikasi Posisi (Position Identification); dan Tahap (3) Integrasi sistem (System integration).

Pada tahap awal atau tahap function reinforcement, fokus perusahaan masih bersifat internal. Perusahaan berupaya untuk merasionalisasi atau minimal memerkuat fungsifungsi dari semua bagian atau departemen yang ada menuju ke arah "orientasi tujuan" dalam menyikapi lingkungan bisnis yang berubah cepat dan unpredictable. Upaya memperkuat fungsi dapat dilakukan jika fungsi-fungsi yang ada sudah dirasa tepat untuk mencapai tujuan perusahaan. Jika harus dilakukan rasionalisasi atas fungsifungsi yang ada tersebut, perusahaan harus mengedepankan prinsip quick-respons organization (flat organization). Bagaimana pun juga prinsip ini merupakan alternatif tunggal atas model organisasi yang dapat digunakan di era digital (Estaswara, 2008a). Quick-respons organization atau flat organization merupakan model perusahaan dengan struktur yang ramping sehingga mampu bergerak cepat dan lincah dalam merespons lingkungan bisnis yang unpredictable hari ini. Dalam waktu yang bersamaan, perusahaan juga harus mulai berinvestasi pada teknologi informasi. Teknologi informasi digunakan untuk memperkuat fungsifungsi yang ada dalam perusahaan, dengan tujuan menciptakan aliran informasi (data) dan komunikasi yang lancar antar subbagian, bagian, departemen sampai kantor cabang, baik yang berlokasi di daerah, nasional sampai internasional. Dengan strategi seperti ini, semua bagian tersebut akan terkoneksi satu dengan yang lainnya dan well informed terhadap perkembangan-perkembangan informasi perusahaan dalam rangka pencapaian tujuan.

Pada tahap kedua atau position identification, perusahaan mulai mengidentifikasi posisinya dalam sistem sosial yang terbentuk di era digital society. Peran riset tentang stakeholder dan bagaimana pola hubungannya, pada tahap ini menjadi sangat krusial. Hanya melalui riset, posisi perusahaan dapat diidentifikasi secara tepat dan bertanggungjawab. Riset yang dilakukan tidak semata-mata hanya tentang feed-back dari para stakeholder-nya atas informasi mengenai program-program perubahan perusahaan yang telah dilakukan di tahap pertama (program evaluation), namun lebih dari itu harus terkait dengan keseluruhan perilaku stakeholder dalam konteks sistem jaringan, termasuk di dalamnya perilakunya atas digital media, khususnya SNSs. melalui riset-risetnya seputar stakeholder relations, perusahaan sebenarnya sudah mengaplikasikan model komunikasi dua arah walaupun masih bersifat asimetrik-communication as an interaction (West \& Turner, 2007) atau melakukan exploring (van Woerkum \& Aarts, 2008), walaupun pada titik tertentu masih tetap menggunakan pendekatan informing (positioning). Di samping itu, teknologi informasi juga telah diaplikasikan secara internal, sehingga fungsi informasi (data) dan komunikasi antar departemen dan kantor cabang dapat berjalan lancar. Sistem komunikasi organisasi yang berbasis pada teknologi informasi ini memiliki arti yang sangat penting karena menjadi kondisi (prasyarat) yang harus dipenuhi untuk bisa memasuki tahap transformasi berikutnya. 
Tabel 1.

Fase dan Tahap Transformasi Model Stakeholder Relationship

\begin{tabular}{|c|c|c|}
\hline $\begin{array}{c}\text { CORPORATE-CENTRIC } \\
\text { MODEL }\end{array}$ & \multicolumn{2}{|c|}{ SYSTEM-CENTRIC MODEL } \\
\hline INSIDE-OUT PHASE & \multicolumn{2}{|c|}{ OUTSIDE-IN PHASE } \\
\hline $\begin{array}{l}\text { Function Reinforcement } \\
\text { (1st Stage) }\end{array}$ & $\begin{array}{l}\text { Position Identification } \\
\text { (2nd Stage) }\end{array}$ & $\begin{array}{c}\text { System Integration } \\
\text { (3rd Stage) }\end{array}$ \\
\hline $\begin{array}{l}\text { - Memperkuat (atau } \\
\text { merasionalisasi) fungsi } \\
\text { semua departemen yang } \\
\text { ada dalam perusahaan. } \\
\text { - Pada tahap ini fokus } \\
\text { perusahaan adalah } \\
\text { penguatan fungsi } \\
\text { internal dengan aplikasi } \\
\text { teknologi informasi. }\end{array}$ & $\begin{array}{l}\text { - Mengidentifikasi dan } \\
\text { mendefinisikan posisi } \\
\text { perusahaan dalam sistem } \\
\text { sosial di era digital society. } \\
\text { - Pada tahap ini } \\
\text { perusahaan mulai } \\
\text { menggali pemahaman } \\
\text { yang mendalam tentang } \\
\text { semua stakeholder } \\
\text { perusahaan melalui riset } \\
\text { yang berbasis teknologi } \\
\text { informasi. }\end{array}$ & $\begin{array}{l}\text { - Perusahaan } \\
\text { terintegrasi dalam sistem } \\
\text { sosial di era digital } \\
\text { society. } \\
\text { - Telah terbangunnya } \\
\text { integrasi sistem informasi } \\
\text { internal sebagai dasar } \\
\text { dalam membangun } \\
\text { hubungan yang saling } \\
\text { menguntungkan dalam } \\
\text { jangka panjang dengan } \\
\text { para stakeholder-nya. }\end{array}$ \\
\hline
\end{tabular}

\section{MULTI-STAKEHOLDER LEARNING}

- Perusahaan aktif menginformasikan tahap awal perubahan kepada para stakeholdernya dengan tujuan penciptaan awareness dan knowledge (information campaign).

- Pada tahap ini perusahaan masih fokus pada one-way communication model atau communication as an action.
- Perusahaan sudah aktif untuk mencari feed-back dari para stakeholder-nya terkait dengan awareness dan knowledge atas perubahan yang dilakukan oleh perusahaan (Exploring dan Positioning).

- Pada tahap ini perusahaan sudah mulai - Pada tahap ini perusahaan mengaplikasikan model sudah menerapkan model two-way communication two-way communication namun masih bersifat yang bersifat simetrik asimetrik atau atau communication as a communication as an transaction.

- Perusahaan aktif berdialog dengan para stakeholder-nya sebagai proses penciptaan saling pengertian antara kedua belah pihak dalam konteks jaringan di era digital society (Exploring, Relating dan Negotiating) interaction. 
Tahap perubahan yang terakhir adalah tahap system integration. Pada tahap ini perusahaan telah mengimplementasikan integrasi sistem informasi internal sebagai dasar dalam membangun hubungan jangka panjang yang saling menguntungkan dengan para stakeholder-nya (Estaswara, 2008a). Dengan mengaplikasikan teknologi komunikasi dan informasi, perusahaan telah memiliki kapasitas untuk mengintegrasikan dirinya dengan sistem jaringan sosial yang terbentuk di era digital society atau terintegrasi secara internal dan integrasi internal ini juga terintegrasi secara eksternal. Untuk lebih memudahkan, konsep ini dapat disebut dengan total integration. Bagaimanapun juga perusahaan yang mampu menjalankan model system centric dalam konteks stakeholder relations adalah perusahaan yang memiliki basis integrated information technology (technological resources) yang kuat secara internal, sehingga memudahkan dirinya terintegrasi dengan sistem eksternal, secara terukur dan terkontrol, sehingga dapat terus dimonitor dan dievaluasi.

Pada tahap system integration, perusahaan telah aktif melakukan multi-stakeholders learning dialogues dengan para stakeholder-nya sebagai proses penciptaan saling pengertian dalam konteks jaringan komunikasi dan sosial di era digital society, baik melalui negosiasi maupun persuasi dengan tujuan untuk mencapai konsensus (Grunig \& Grunig; 1992; Ledingham, 2003; van Ruler, 2004) atau menurut van Woerkum \& Aarts (2008), dapat dilakukan dengan cara exploring, relating dan negotiating. Tujuan utama terciptanya dialog simetris ini adalah pembangunan hubungan dalam jangka panjang yang saling menguntungkan antara perusahaan dengan stakeholder-nya. Sehingga dapat dikatakan bahwa di tahap ini perusahaan sudah menerapkan model two-way communication yang bersifat simetrik (West \& Turner, 2007; Estaswara, 2011a, 2011b). Secara umum, tahap position identification dan system integration disebut sebagai fase outside-in, karena perusahaan sudah berkomitmen penuh terhadap terciptanya kualitas hubungan dengan semua stakeholder-nya melalui prinsip-prinsip dialog (Estaswara, 2010) dalam kompleksitas sistem jaringan sosial.

\section{SIMPULAN}

Gagasan tentang corporate crisis dan stakeholder relationship model yang dipresentasikan dalam tulisan ini secara internasional dan dalam konteks disiplin ilmu komunikasi bukan sesuatu yang baru, meskipun studi tentang stakeholder relations model di era digital society di Indonesia masih dapat dikatakan relatif jarang. Di sisi lain, studi ini memberikan gambaran umum dan komprehensif serta berangkat dari sudut pandang yang berbeda dalam memahami bagaimana melakukan tindakan preventif dalam mengelola corporate crisis melalui stakeholder relations beserta pemodelannya dengan tujuan agar aktivitas bisnis perusahaan tetap berjalan selaras dengan kompleksitas perubahan teknologi informasi dan komunikasi dewasa ini.

Pendekatan sistem-centric yang telah dimodelkan dalam tulisan ini sebenarnya dikembangkan dari perspektifnya Lozano (2008) mengenai building stakeholder relations - tanpa mengurangi arti pentingnya model stakeholder yang pernah tuliskan oleh Fill (2006:206) dan para pemikir komunikasi lain dalam konteks digital media-model yang diajukan dalam tulisan ini dapat digunakan sebagai dasar dalam memahami bagaimana perusahaan harus membangun hubungan yang saling menguntungkan dalam jangka panjang dengan para stakeholder-nya, baik bagi kalangan akademisi maupun praktisi komunikasi untuk merespons kompleksitas persoalan di era digital society dan mencegah krisis dalam perusahaan.

Walaupun penjelasan mengenai tahaptahapan transformasi model stakeholder relationship dalam tulisan ini telah diuraikan secara runut, namun masih tetap dibutuhkan studi lanjutan mengenai pentingnya transformasi organisasi dalam kompleksitas sistem berbasis paradigma postmodernism, interaksi cyber dan kebutuhan budaya organisasi dalam pengelolaan hubungan dengan stakeholder dalam konteks teori instrumental, serta program-program komunikasi yang spesifik, terukur dan dapat dievaluasi di setiap tahapan beserta strategi dan tujuan komunikasinya. Di samping itu, dibutuhkan juga kajian yang lebih mendalam terkait dengan model stakeholder relationship yang ditawarkan dalam tulisan ini dengan model-model umum lainnya yang telah dipublikasikan, sehingga dapat menghasilkan big picture of reality secara lebih lengkap. 


\section{DAFTAR PUSTAKA}

Ardani, B. D. (2010), "The Prita Mulyasari case: The practice of democracy and citizen participation in the era of digital media." Proceedings of Indonesia International Conference on Communication (Indo-ICC)-Global Challenge to the Future of Communication, Digital Media and Communication Freedom in Public Discourse. 22-23 November 2010, Jakarta, Indonesia.

Boyd, D. M. \& Ellison, N. B. (2008), Social NetworkSites: Definition, History, and Scholarship." Journal of Computer-Mediated Communication, Vol. 13(1).

Burke, P. (2000). A social history of knowledge: From Gutenberg to Diderot. Cambridge, UK: Polity Press.

Calloway, L. J. \& Keen, P. G. W. (1996), Organizing for Crisis Responsse." Journal of Information Technology, 11, 13-26.

Coombs, W. T. (2009), Conceptualizing Crisis Communication." dalam Heath, L. R. \& H. Dan O'hair (Eds.). Handbook of Risk and Crisis Management. London: Raoudledge, 99-118.

Cooper, H. M. (1988). Organizing knowledge synthesis: A taxonomy of literature reviews. Knowledge in Society, 1, 104-126.

Craig, E. M. (2007), Seneca's Internet: A Preliminary Review of YouTube and its Implications for Digital Media. The Journal of the International Digital Media and Arts Association, Vol. 4(1).

D'Aveni, R. A. (1994), Hypercompetition: Managing the dynamics of strategic maneuvering. New York: The Free Press.

De Bruyn, A., \& G. L. Lilien. (2008), A multi-stage model of word-of-mouth influence through viral marketing." International Journal of Research in Marketing, 25, 151-163.

De Saez, E. E. (2002), Marketing Concepts for Libraries and Information Services, (2nd Ed.). London: Facet Publications.

Eid, M. \& Stephen J. A. W. (2009), Ethics, New Media, and Social Networks. Global Media Journal, Vol. 2(1), 1-4.

Estaswara, H. (2008a), Think IMC: Efektivitas Komunikasi untuk Meningkatkan Loyalitas Merek dan Laba Perusahaan. Jakarta: Gramedia Putaka Utama.

. (2008b), The Implementation Process of IMC (Integrated Marketing Communications) and Its Future Prospect in Business Practice in Indonesia: An Exploratory Comparative Study toward Four Profession Groups. Indonesia Journal of Communication Studies, Vol. 1(1), 73-83.

(2010), Stakeholder Relationship in Integrated Marketing Communications (IMC): A Theoretical Perspective. CoverAge: Scientific Journal of Strategic Communication, Vol. 1(1): 61-75.

(2011a), Corporate Cyber-Crisis: A Case Study of Omni International In Indonesia. Journal of Modern Accounting \& Auditing, Vol. 7 (8).

(2011b), "Computer-Mediated Public Sphere" and Stakeholder Relationships Model. International Journal of Arts \& Sciences. CDROM. ISSN: 1944-6934, Vol. 4(7), 99-112.

Fearn-Banks, K. (2009), "Crisis Communication" dalam Eadie, W. F. (Ed.). 21st Century Communication: A Reference Handbook: California: Sage Publication, 741-748.

(1996), Crisis Communication: A Case book Approach. Mahwah. NJ: Lawrence Erlbaum.

Fink, S. (1986). Crisis management: Planning for the inevitable. New York: AMACOM.

Fill, C. (2006), Marketing ommunications: Enggagement, Strategies and Practice. (4rd Ed.) UK: Prentice Hall.

Gangadharbatla, H. (2008), Facebook Me: Collective Self-Esteem, Need to Belong, andlnternet Self-Efficacy as Predictors of the Igeneration's Attitudes toward Social Networking Sites. Journal of Interactive Advertising, Vol 8(2), 5-15.

Guth, D. W., \& C. Marsh. (2003), Public Relations: A Value-Driven Approach. (2nd Ed.) Boston, US: Allyn \& Bacon.

Grunig, J. E. \& Grunig, L. A. (1992), "Models of public relations and communication." dalam Grunig, J. E. (Ed.), Excellence in public relations and communication management. Hillsdale, $\mathrm{NJ}$ : Lawrence Erlbaum, 285-325.

\& Repper, F. C. (1992), "Strategic management, publics, and issues." dalam Grunig, J. E. (Ed.), Excellence in public relations and communication management. Hillsdale, NJ: Lawrence Erlbaum, 117-157. 
Harbermas, J. (1974). The Public Sphere: An Encyclopedia Article. New German Critique, No. 3, 49-55.

Hallahan, K. (2009), "Crisis and Risk in Cyberspace." dalam Heath, L. R. \& H. Dan O'hair (Eds.). Handbook of Risk and Crisis Management. London: Roudledge, 412-445.

Hennig-Thurau, T., Kevin P. G., Gianfranco W., \& Dwayne D. G. (2004), Electronic Word-ofMouth via Consumer-Opinion Platforms: What Motivates Consumers to Articulate Themselves on the Internet? Journal of Interactive Marketing, 18(1), 38-52.

Jordan, K., J. Hauser, \& S. Foster. (2003), The Augmented Social Network: Building Identity and Trust into the Next-Generation Internet. First Monday, Peer-Reviewed Journal in the Internet, Vol. 8(8). Diakses dari http:// firstmonday.org/htbin/cgiwrap/bin/ ojs/index.

Kuchi, T. (2006), Constant change and the strategic role of communication: A selective annotated bibliography. Library Management Vol. 27(4/5), 218-235.

Ledingham, J. A. (2003), Explicating relationship management as a general theory of public relations. Journal of Public Relations Research, Vol. 15(2), 181-98.

Lozano, J. M. (2005), Towards the relational corporation: from managing stakeholder relationships to building stakeholder relationships (Waiting for Copernicus). Corporate Governance, Vol. 5(2), 60-77.

Mantovani, F. (2001), "Cyber-Attraction: The Emergence of Computer-Mediated Communication in the Development of Interpersonal Relationships." Dalam Anolli, R. C., \& G. Riva (Eds.) New perspectives on miscommunication. (pp. 236-250). Amsterdam, Holand: IOS Press.

McLoughlin, C., \& Mark J. W. Lee. (2008), Mapping the digital terrain: New media and social software as catalysts for pedagogical change. Proceedings Ascilite Melbourne 2008.

Mitchell, R. K., Agle, B. R. \& Wood, D. (1997), Toward a theory of stakeholder identification and salience: defining the principle of who and what really counts. Academy of Management Review, Vol. 22(4), 853-86.

Mitroff, I. I. (2004). Crisis leadership: Planning for the unthinkable.Hoboken, NJ: Wiley.
Mitroff, I. I., \& Anagnos, G. (2001). Managing crises before they happen. New York: AMACOM.

Mitroff, I. I., Harrington, L. K., \& Gai, E. (1996). Thinking about the unthinkable. Across the Board, Vol. 33(8), 44-48.

Mitroff, I. I., \& Pearson, C. M. (1993). Crisis management: Diagnostic guide for improving your organization's crisis-preparedness. San Francisco: Jossey-Bass.

Morsing, M., \& Schultz, M. (2006), Corporate social responssibility communication: Stakeholder information, responsse and involvement strategies. Business Ethics: A European Review, Vol. 15(4), 323-338.

Murphy, P. (2000). Symmetry, contingency, complexity: Accommodating uncertainty in public relations theory. Public Relations Review, 26(4), 447-62.

Owen, R. \& R. Humphrey. (2009), The structure of online marketing communication channels. Journal of Management and Marketing Research, Vol. 2, 5-8.

Preston, L.E., \& Sapienza, H.J. (1990), Stakeholder management and corporate performance. The Journal of Behavioral Economics, Vol. 19(4), 361-375.

Parks, M. R., \& Floyd, K. (1996), Making friends in cyberspace. Journal of Communication, Vol. $46,80-97$.

Rajasekera, J. (2010), Crisis Management in Social Media and Digital Age: Recall Problem and Challenges to Toyota. GSIM Working Paper, No. IM-2010-02.

Richardson, K. A., \& Cilliers, P. (2001). What is complexity science? A view from different directions. Emergence, 3(1), 5-22.

Rowley, T. J. (1997), Moving beyond dyadic ties: a network theory of stakeholders influences. Academy of Management Review, Vol. 22(4), 887-910.

Shankar, V, Smith, A. K., \& Rangaswamy, A. (2003), Customer satisfaction and loyalty in online and offline environments. International Journal of Research in Marketing, 20, 153-175.

Ströh, U., \& M. Jaatinen, M. (2001), New approaches to communication management for transformation and change in organizations. Journal of Communication Management Vol. 6(2), 148-165.

Vilpponen, A., Susanna W., \& Sanna S. (2006), Electronic Word-of-Mouth in Online 
Environments: Exploring Referral Networks Structure and Adoption Behaviour. Journal of Interactive Advertising, Vol 6(2), 63-77.

van Ruler, B. (2004), The communication grid: introduction of a model of basic communication strategies in public relations. Public Relations Review, Vol. 30(2), 123-143.

van Woerkum, C. \& Aarts, N. (2008), Staying connected: The communication between organizations and their environment. Corporate Communications: An International Journal, Vol. 13(2), 197-211.

van Uden, J., Richardson, K. A., \& Cilliers, P. (2001). Postmodernism revisited? Complexity science and the study of organisations. Tamara: Journal of Critical Postmodern Organization Science, Vol. 1(3), 53-67.

West, R., \& Turner, L.H. (2007), Introducing communication theory: Analysis and application (3rd Ed.). New York: McGraw-Hill.

Werther, W. B., \& Chandler, D. (2006), Strategic Corporate Responssibility: Stakeholders in a Global Environment. New Delhi: Sage Publication.

"Responsding to crisis using social media: Updating the "Dell Hell" case study-are Dell turning opinion round?" Market Sentinel, 2007.

“Menulis di Internet Dipenjara: 'Bebaskan Prita' Gencar di Facebook. (02/06/2009) Diakses dari http://www.detiknews.com/read/2009/06/02 /120204/1141289/10/bebaskan-prita-gencardi-facebook. Edisi 02/06/2009. 